\title{
Report on the Medicinal Use of Eleven Lamiaceae Species in Lebanon and Rationalization of Their Antimicrobial Potential by Examination of the Chemical Composition and Antimicrobial Activity of Their Essential Oils
}

\author{
Madona Khoury, ${ }^{1,2}$ Didier Stien, ${ }^{1,3}$ Véronique Eparvier, ${ }^{1}$ \\ Naïm Ouaini, ${ }^{2}$ and Marc El Beyrouthy ${ }^{2}$ \\ ${ }^{1}$ CNRS, Institut de Chimie des Substances Naturelles, UPR 2301, 1 Avenue de la Terrasse, 91198 Gif-sur-Yvette, France \\ ${ }^{2}$ Department of Agricultural Sciences, Holy Spirit University of Kaslik, Kaslik, B.P. 446, Jounieh, Lebanon \\ ${ }^{3}$ Sorbonne Universités, UPMC Univ Paris 06, CNRS, Laboratoire de Biodiversité et Biotechnologies Microbiennes (LBBM), \\ Observatoire Océanologique, 66650 Banyuls-sur-mer, France \\ Correspondence should be addressed to Didier Stien; didier.stien@cnrs.fr and Marc El Beyrouthy; marcelbeyrouthy@usek.edu.lb
}

Received 4 July 2016; Revised 29 September 2016; Accepted 4 October 2016

Academic Editor: Nativ Dudai

Copyright (C) 2016 Madona Khoury et al. This is an open access article distributed under the Creative Commons Attribution License, which permits unrestricted use, distribution, and reproduction in any medium, provided the original work is properly cited.

\begin{abstract}
Many Lamiaceae species are consumed in the Lebanese cuisine as food or condiment and are largely used in the traditional medicine of Lebanon to treat various diseases, including microbial infections. In this article we report the traditional medicinal uses of eleven Lamiaceae species: Coridothymus capitatus L., Lavandula stoechas L., Lavandula angustifolia Mill., Mentha spicata L. subsp. condensata, Origanum syriacum L., Rosmarinus officinalis, Salvia fruticosa Miller., Satureja cuneifolia Ten., Satureja thymbra L., Thymbra spicata L., and Vitex agnus-castus L. and study the chemical composition and antimicrobial activity of their essential oils (EOs). Our survey showed that Lamiaceae species are mainly used against gastrointestinal disorders and microbial infections. Chemical analysis of the EOs obtained from these plants allowed us to identify seventy-five compounds describing more than $90 \%$ of the relative composition of each EO. Essential oils with high amounts of thymol and carvacrol possessed the strongest antimicrobial activity. As expected, these two compounds demonstrated an interesting antifungal efficacy against the filamentous fungus T. rubrum. Our results confirmed that some of the Lamiaceae species used in Lebanon ethnopharmacological practices as antimicrobial agents do possess antibacterial and antifungal potential consistent with their use in alternative or complementary medicine.
\end{abstract}

\section{Introduction}

The evolution of resistance to currently used antimicrobial compounds is neither a surprising nor a new phenomenon; however, infections are becoming more common, more severe, and more easily transmitted. According to the WHO, many infectious diseases will become untreatable and uncontrollable in the upcoming years [1]. Many authors mention a possible upcoming postantibiotic era [2-4].

Aromatic plants have been recognized since antiquity and widely used as bactericides, fungicides, virucides, antiparasitics, and pesticides. Their properties are mainly attributed to their volatile oils $[5,6]$. Investigations into the antimicrobial activities, mode of action, and potential uses of plant essential oils have regained momentum [7]. These oils, representative of very wide chemical diversity, may contribute to or inspire alternative solutions against multidrug resistant infections. Recently, in vitro screening programs based on ethnobotanical approaches proved to be very efficient in validating traditional uses of medical plants and providing new ways in the search for active compounds [8].

Lamiaceae (formerly known as Labiatae) is a large plant family of mostly shrubs and herbs. It is the largest family of the order Lamiales with 236 genera and more than 7,000 
species, the largest genus being Salvia with around 900 species [9]. Lamiaceae are distributed globally and a particularly high concentration of them occurs in the Mediterranean region. The majority of Lamiaceae being aromatic plants, the family is economically important [10]. Many are cultivated as ornamentals, like Ajuga, Coleus, and Salvia but others are widely used as culinary herbs and spices, such as sage (Salvia), thyme (Thymus), mint (Mentha), oregano or marjoram (Origanum), rosemary (Rosmarinus), lavender (Lavandula), and basil (Ocimum). Mint and lavender are grown for their oil used in perfumery, cosmetics, pharmaceutical, and food industries as active ingredients or as flavour and fragrance. Medicinal properties of the Lamiaceae species are often attributed to their high content of volatile compounds.

The Lamiaceae family is particularly well represented in Lebanon, where 136 species belonging to 29 genera have been inventoried [11]. Many Lamiaceae are regularly consumed in the Lebanese cuisine as food or condiments. For example, the different varieties of thyme like Origanum syriacum, Satureja thymbra, and Thymbra spicata associated with a mixture of Rhus coriaria L. (sumac) and sesame seeds are the main ingredients of a very popular Lebanese pizza called "manakeesh." Others, like Rosmarinus officinalis, Coridothymus capitatus, and Salvia fruticosa, are eaten as salads and the leaves of Thymus and Origanum species are mixed with traditional Lebanese fresh cheese called "Shanklish" for their aromatic and antiparasitic properties.

Indigenous Lamiaceae are also frequently used in Lebanon for medical purposes and are marketed by herbalists. These include the genera Lavandula, Melissa, Mentha, Origanum, Rosmarinus, Salvia, Satureja, and Thymus. These plants are highly aromatic due to the presence of external glandular structures that produce volatile oil [12] and their essential oils are widely used in the Lebanese folk medicine $[11,13,14]$.

However, there was no previous study documenting the folk medicinal usage of the Lamiaceae species in Lebanon. We have conducted a large-scale survey on the traditional medicinal uses of Lamiaceae species in different regions of Lebanon. A part of this work has already appeared in a congress report [11].

The main objectives of the present study were (1) to report on the traditional uses of eleven Lamiaceae species most used in the Lebanese folk medicine (Coridothymus capitatus L. Reichenb. Fil., Lavandula stoechas L., Lavandula angustifolia Mill., Mentha spicata L. subsp. condensata, Origanum syriacum L., Rosmarinus officinalis L., Salvia fruticosa Miller., Satureja cuneifolia Ten., Satureja thymbra L., Thymbra spicata L., and Vitex agnus-castus L.), (2) to investigate the chemical composition of the EOs extracted from these species, (3) to evaluate the antimicrobial activity of these EOs and their major constituents against opportunistic human pathogens, and (4) to correlate in vitro results with the ethnopharmacological uses of these plants.

\section{Material and Methods}

2.1. Ethnomedical Field Survey and Ethnobotanical Data Collection. The research was carried out in different regions of Lebanon from the north to the south and from the coast to the mountains, including the anti-Lebanon mountain range and the steppe. A great variety of wild plant species according to different ecological conditions can therefore be found. The surveys were conducted in the cities and villages of the twenty-five districts ("aqdya" or "qadaa") of the six governorates ("mohaafazah") of Lebanon (Figure 1).

Ethnobotanical and ethnomedicinal information was obtained between the years 2002 and 2008 from 325 interviewees from 223 villages covering all the districts of Lebanon. Most of the participants interviewed were herbalists ("Attarin" or "dabbous"), shepherds, farmers, folk healers, or older experienced people and midwives ("daye") between 40 and 70 years old. The people interviewed declared that their knowledge about the traditional medicine was transmitted mainly orally from older generations. Interviewees were accompanied to the field individually where they would point out the herbs that have been using to cure the mentioned disease. This was also to confirm plant identification (vernacular names can be different in different regions of Lebanon) and obtain fresh samples for herbarium voucher. When the fertile part was not available, the plant was visited again at the appropriate time to obtain a fertile sample.

The obtained information was cross-checked with that of other informants, and also, after a week, the interview was repeated with the same person. Only medical usages of plants given at least by three separate informants have been reported in this investigation. It was verified that each informant is able to recognize the mentioned plant species in the wild.

The questionnaire form was based on the botanical and ethnopharmacognosic survey of traditional medicine plants, suggested by WHO [15]. The collected information included local names, used part(s) of the plant, folk medicinal uses and therapeutic properties, method of preparation, way of administration, doses, and duration of treatment. The results are recorded in a synoptic table (Table 2 ).

2.2. Plant Material. Plant material was collected in several locations throughout Lebanon and voucher specimens were deposited at the Herbarium of Botany of the U.S.E.K., Lebanon. Specimens of the Lamiaceae species were collected as described in Table 1.

The plants have been identified based on the "Nouvelle flore du Liban et de la Syrie" (Mouterde) [16] and the MedChecklist (http://ww2.bgbm.org/mcl/). We followed the new phylogenetic classification APG II [17] in order to update the families cited in Mouterde. Voucher specimens were deposited at the Herbarium of Botany of the U.S.E.K., Lebanon.

2.3. Essential Oil Extraction. The essential oils (EOs) were obtained by hydrodistillation performed for $3 \mathrm{~h}$ using a Clevenger-type apparatus according to the European Pharmacopoeia [18]. Yields are given in Table 4.

\subsection{Essential Oils Analyses}

2.4.1. GC Analyses. Analytical gas chromatography was carried out on a Thermo Electron Corporation gas 


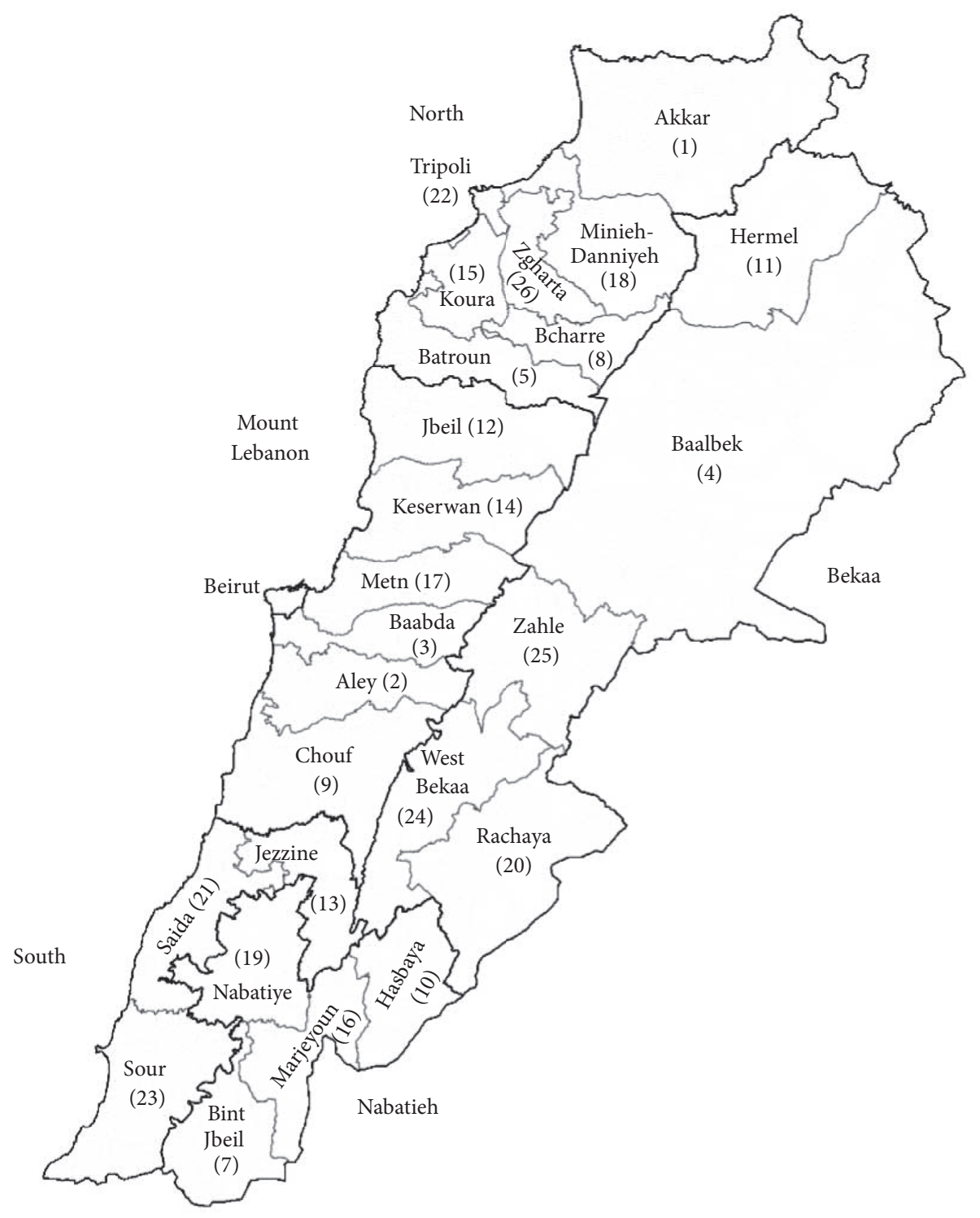

FIGURE 1: Studied area: the governorates and districts of Lebanon.

chromatograph fitted with a DB-5 MS capillary column $(30 \mathrm{~m} \times 0.25 \mathrm{~mm})$ with $0.1 \mu \mathrm{m}$ film thickness or a fused silica HP Innowax polyethylene glycol capillary column $(50 \mathrm{~m} \times$ $0.20 \mathrm{~mm}$, film thickness $0.20 \mu \mathrm{m})$. Helium was the carrier gas $(0.7 \mathrm{~mL} / \mathrm{min})$. The column temperature was initially set to $35^{\circ} \mathrm{C}$ before being gradually increased to $85^{\circ} \mathrm{C}$ at $5^{\circ} \mathrm{C} / \mathrm{min}$, held for $20 \mathrm{~min}$ at $85^{\circ} \mathrm{C}$, raised to $300^{\circ} \mathrm{C}$ at $10^{\circ} \mathrm{C} / \mathrm{min}$, and finally held for $5 \mathrm{~min}$ at $300^{\circ} \mathrm{C}$. Diluted $1 \mu \mathrm{L}$ samples $(1 / 100$, $\mathrm{v} / \mathrm{v})$ were injected at $250^{\circ} \mathrm{C}$ manually and in the splitless mode. Flame ionisation detection (FID) was performed at $310^{\circ} \mathrm{C}$.

2.4.2. GC/MS Analyses. The GC/MS analyses were performed using an Agilent 6890 gas chromatograph coupled with 5975 Mass Detector. The 7683B autosampler injected $1 \mu \mathrm{L}$ of each oil sample. A fused silica capillary column DB5 MS $(30 \mathrm{~m} \times 0.25 \mathrm{~mm}$ internal diameter, film thickener
$0.1 \mu \mathrm{m})$ or a fused silica HP Innowax polyethylene glycol capillary column $(50 \mathrm{~m} \times 0.20 \mathrm{~mm}$, film thickness $0.20 \mu \mathrm{m})$ was used. Helium was the carrier gas $(0.7 \mathrm{~mL} / \mathrm{min})$. The oven temperature program was identical to that described in Section 2.4.1. The mass spectra were recorded at $70 \mathrm{eV}$ with an ion source temperature of $310^{\circ} \mathrm{C}$ and a transfer line heated to $320^{\circ} \mathrm{C}$. The acquisition was recorded in full scan mode (50$400 \mathrm{amu})$.

2.4.3. Identifications and Quantifications. Most constituents were identified by gas chromatography by comparing their retention indices (RI) with those from the literature $[19,20]$ or with those of authentic compounds obtained from SigmaAldrich (Lebanon). The retention indices were determined relatively to a homologous series of $n$-alkanes (C8 to C24) analysed under the same operating conditions. Further identification was obtained by comparing their mass spectra on 
TABLE 1: Plant material collection information.

\begin{tabular}{|c|c|c|c|c|c|c|c|}
\hline \multirow{2}{*}{ Plant name } & \multirow{2}{*}{ Part used } & \multicolumn{4}{|c|}{ Collection region } & \multirow{2}{*}{ Collection date } & \multirow{2}{*}{$\begin{array}{l}\text { Voucher } \\
\text { number }\end{array}$} \\
\hline & & Region & District & GPS Location & Altitude (m) & & \\
\hline $\begin{array}{l}\text { Coridothymus } \\
\text { capitatus }\end{array}$ & Flowering tops & Anfeh & Koura & $\begin{array}{l}34^{\circ} 21^{\prime} 38.69^{\prime \prime} \mathrm{N} \\
35^{\circ} 43^{\prime} 58.96^{\prime \prime} \mathrm{E}\end{array}$ & 8 & August 2011 & MNV191a \\
\hline $\begin{array}{l}\text { Lavandula } \\
\text { angustifolia }\end{array}$ & Flowering tops & Qartaba & Mount Lebanon & $\begin{array}{l}34^{\circ} 05^{\prime} 39.18^{\prime \prime} \mathrm{N} \\
35^{\circ} 50^{\prime} 38.99^{\prime \prime} \mathrm{E}\end{array}$ & 1170 & May 2012 & MNC121 \\
\hline $\begin{array}{l}\text { Lavandula } \\
\text { stoechas }\end{array}$ & Flowering tops & Adonis & Keserwan & $\begin{array}{l}33^{\circ} 58^{\prime} 05.91^{\prime \prime} \mathrm{N} \\
35^{\circ} 36^{\prime} 35.20^{\prime \prime} \mathrm{E}\end{array}$ & 50 & May 2012 & MNV114 \\
\hline Mentha spicata & Flowering tops & Kfarzebian & Mount Lebanon & $33^{\circ} 59^{\prime} 53.43^{\prime \prime} \mathrm{N}$ & 2015 & July 2012 & MNV194 \\
\hline $\begin{array}{l}\text { Satureja } \\
\text { cuneifolia }\end{array}$ & Leaves & 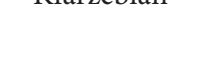 & 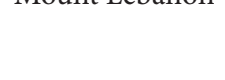 & & 2010 & fury 2012 & MNV173 \\
\hline $\begin{array}{l}\text { Origanum } \\
\text { syriacum }\end{array}$ & Flowering tops & Alita & Keserwan & $\begin{array}{l}34^{\circ} 05^{\prime} 29.72^{\prime \prime} \mathrm{N} \\
35^{\circ} 41^{\prime} 27.05^{\prime \prime} \mathrm{E}\end{array}$ & 620 & August 2012 & MNV188 \\
\hline $\begin{array}{l}\text { Rosmarinus } \\
\text { officinalis }\end{array}$ & Leaves & Shuwayfat & Mount Lebanon & $\begin{array}{l}34^{\circ} 48^{\prime} 32.43^{\prime \prime} \mathrm{N} \\
33^{\circ} 48^{\prime} 32.43^{\prime \prime} \mathrm{E}\end{array}$ & 200 & October 2011 & MNV154 \\
\hline Salvia fruticosa & Leaves & & & $34^{\circ} 04^{\prime} 24.34^{\prime \prime} \mathrm{N}$ & & & MNV159 \\
\hline $\begin{array}{l}\text { Satureja } \\
\text { thymbra }\end{array}$ & Flowering tops & Nahr Ibrahim & Mount Lebanon & $35^{\circ} 39^{\prime} 19.03^{\prime \prime} \mathrm{E}$ & 190 & June 2012 & MNV173a \\
\hline Thymbra spicata & Leaves & & & & & & MNV191 \\
\hline $\begin{array}{l}\text { Vitex } \\
\text { agnus-castus }\end{array}$ & Flowering tops & Nahr Ibrahim & Mount Lebanon & $\begin{array}{l}34^{\circ} 03^{\prime} 42.70^{\prime \prime} \mathrm{N} \\
35^{\circ} 38^{\prime} 44.52^{\prime \prime} \mathrm{E}\end{array}$ & 7 & June 2012 & MNV096 \\
\hline
\end{tabular}

both columns with those provided in the NIST and Wiley 275 libraries, our homemade library constructed with pure compounds, and EOs of known composition or with mass spectra from the literature $[19,21]$. The relative concentrations of the components were calculated based on the GC peak areas without correction; they are reported in Table 4 .

\subsection{Antimicrobial Activity}

2.5.1. Microorganisms. The antimicrobial activity of the essential oils was investigated against the Gram (-) bacterial strain Escherichia coli ATCC 25922, the Gram (+) bacterial strain Staphylococcus aureus ATCC 29213, the yeast Candida albicans ATCC 10231, and a clinical isolate of the dermatophyte Trichophyton rubrum SNB-TR [22].

2.5.2. Microdilution Method. The antimicrobial activity of the EOs was measured using a broth microdilution method according to the Clinical and Laboratory Standards Institute (CLSI) guidelines [23-26]. The essential oils and their major components were diluted in DMSO and were tested at concentrations ranging from 512 to $16 \mu \mathrm{g} / \mathrm{mL}$. The microplates were incubated at $37^{\circ} \mathrm{C}$ for $24 \mathrm{~h}$ for bacteria, $48 \mathrm{~h}$ for yeasts, and 5 days for dermatophytes. The minimal inhibitory concentrations (MIC) refer to the lowest concentrations preventing visible microbial growth (Table 5). Oxacillin and gentamicin $(16-0.03 \mu \mathrm{g} / \mathrm{mL})$ were used as reference antibiotics, while itraconazole $(16-0.03 \mu \mathrm{g} / \mathrm{mL})$ and fluconazole $(64-$ $0.125 \mu \mathrm{g} / \mathrm{mL}$ ) were used as positive controls for the antifungal assays. The antimicrobial standards were purchased from Molekula, Dorset, UK, and the pure terpenes from SigmaAldrich, Lebanon.

\section{Results and Discussion}

3.1. Ethnopharmacological Data. This investigation showed that Lamiaceae species and especially the eleven ones reported in this study are still frequently used in Lebanon as herbal remedies (Table 2). Origanum syriacum and Salvia fruticosa are the two most cited plants. It should be noted that the same vernacular name is sometimes used for different species. For example, the appellation "Zaatar" is used for Satureja thymbra, Thymbra spicata, Coridothymus capitatus, and Origanum syriacum.

3.2. Plant Parts Used. The plant parts used most frequently are the flowering tops and the leaves (34.6\% each), followed by the stems (11.5\%), flowers (7.7\%), whole plant, fruits, and seeds $(3.8 \%$ each) (Table 3$)$.

3.3. Preparation and Administration. Most of the traditional remedies are administered per os or internally $(71.8 \%)$ although the majority of the EOs are applied externally (57.1\%). The main modes of preparation are infusion $(40.0 \%)$, decoction (17.5\%), EO application (17.5\%), and food consumption (15.0\%) (Table 3$)$. The contribution of the volatile organic compounds (VOCs) in all of these preparations is expected to be very important owing to the large amount of VOCs in Lamiaceae. The only exception is for decoctions because this process should eliminate most of the VOCs along with steam.

3.4. Traditional Medicinal Indications. Among the multiple medical usages of these plants, the eleven Lamiaceae species 


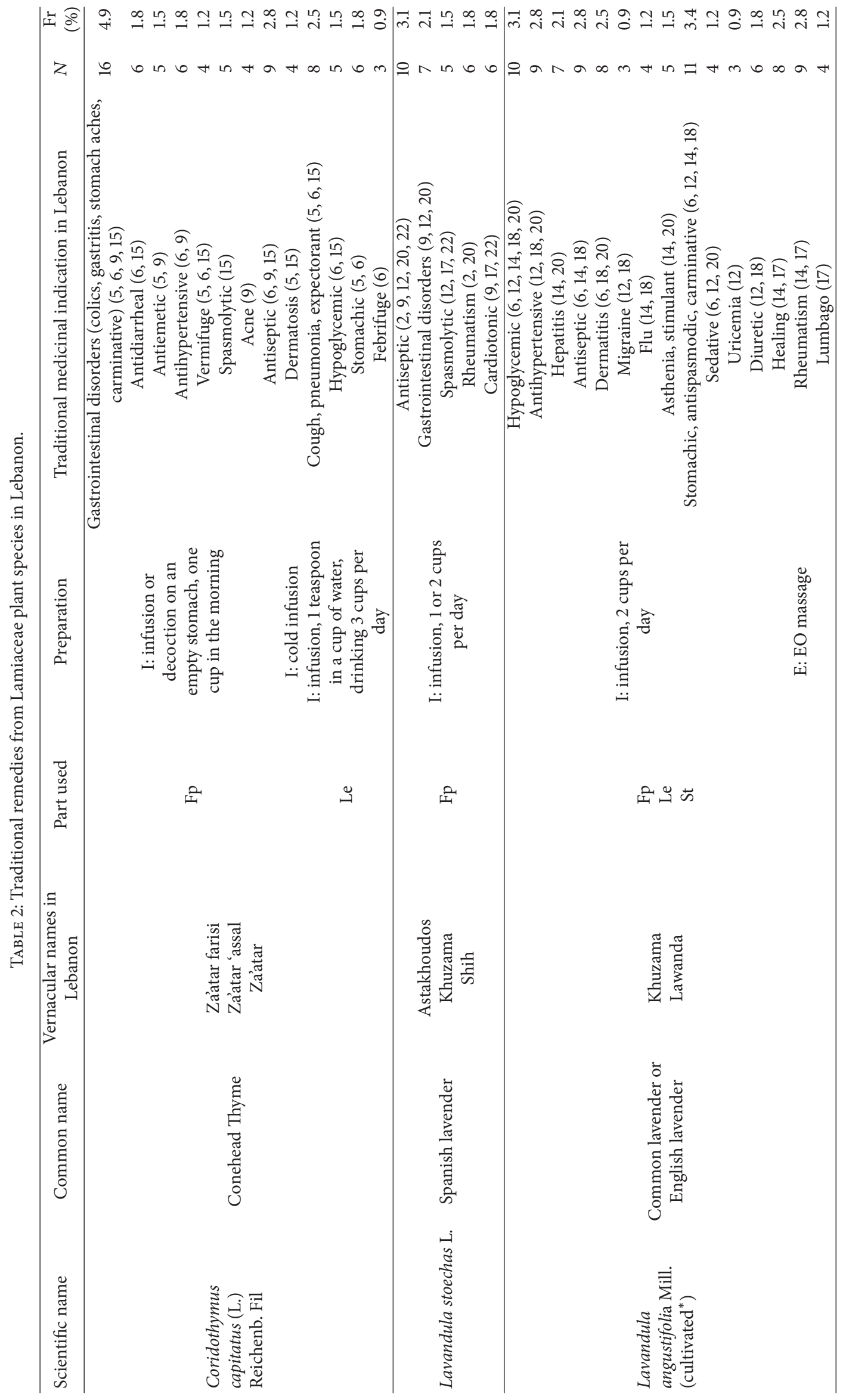




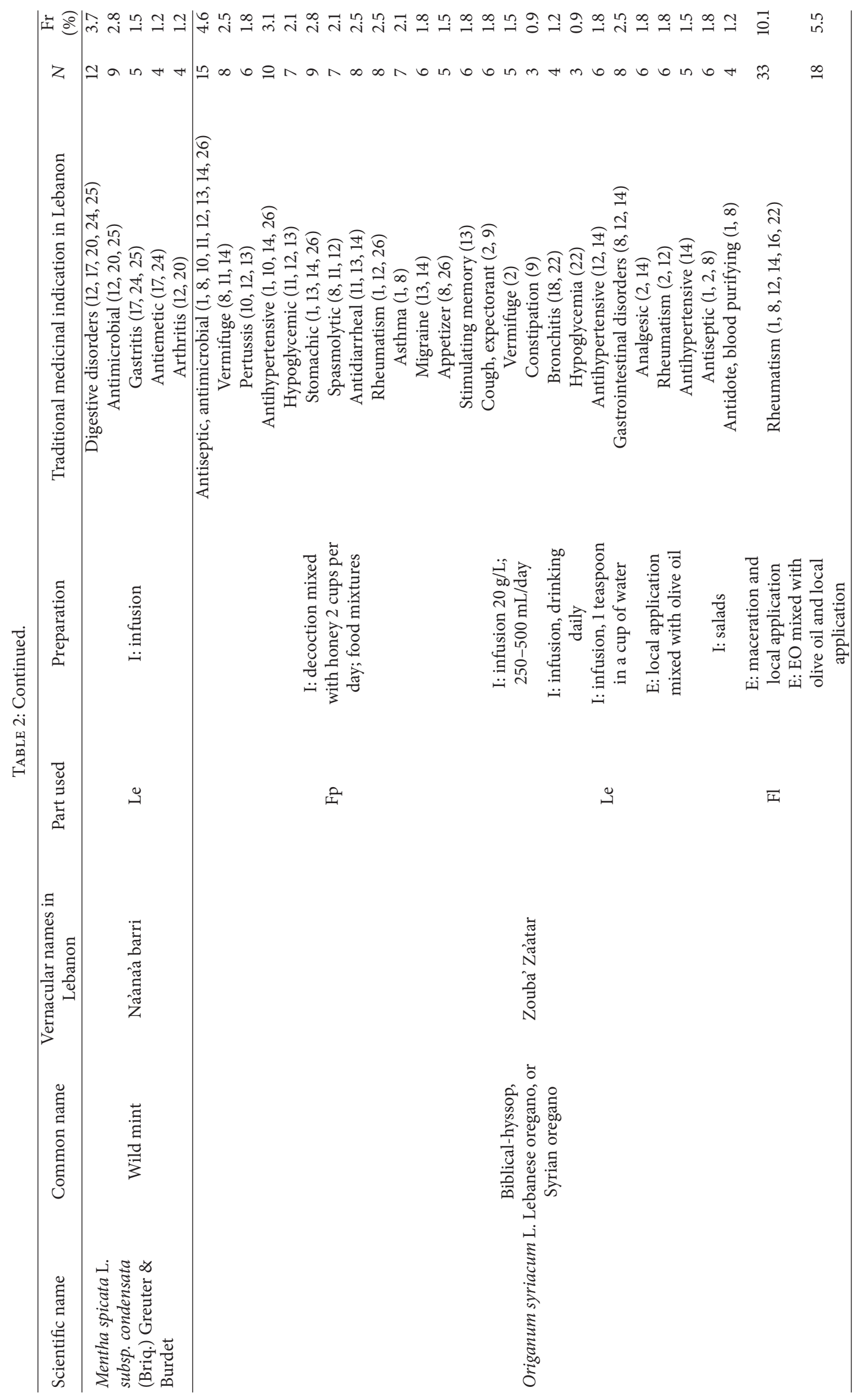




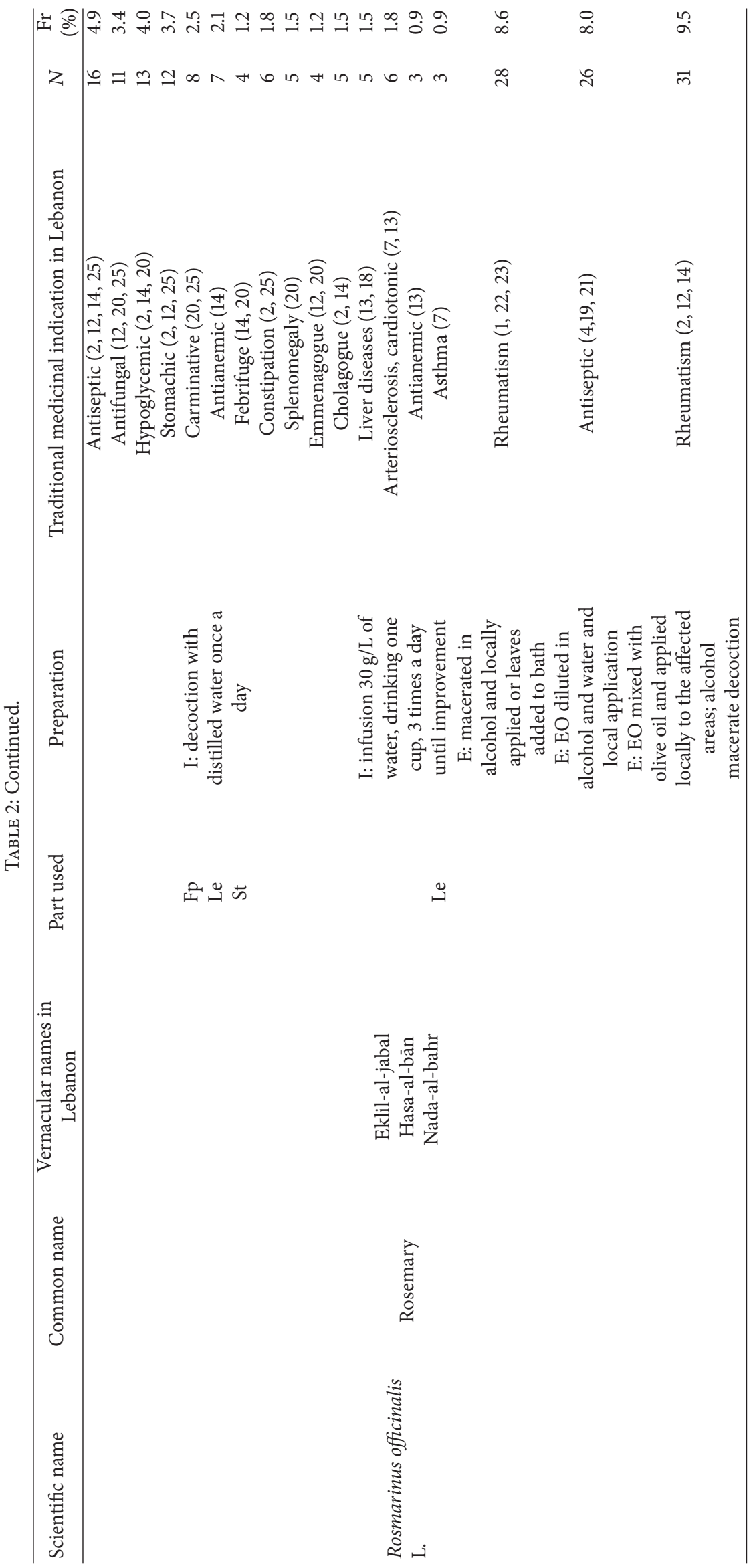




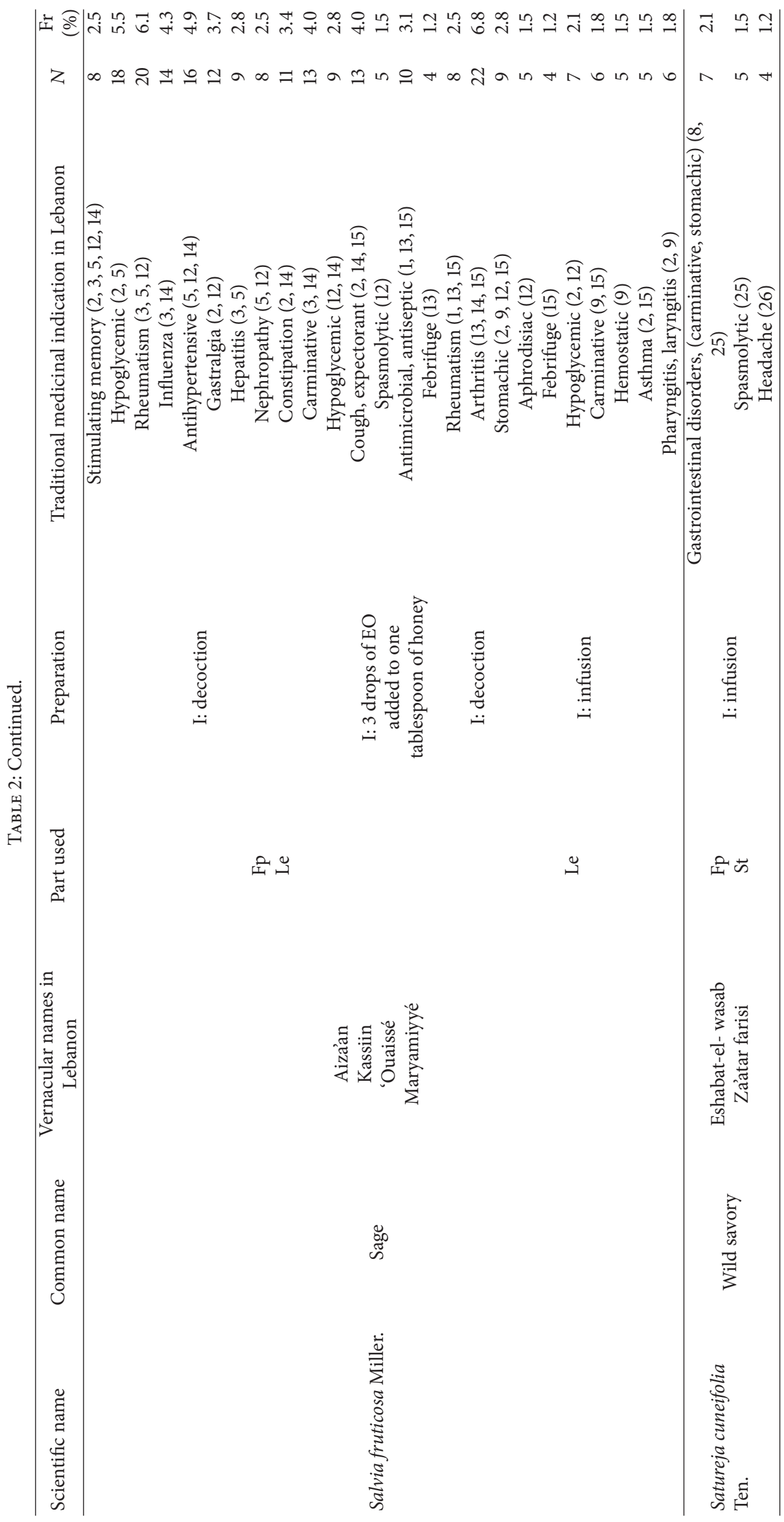




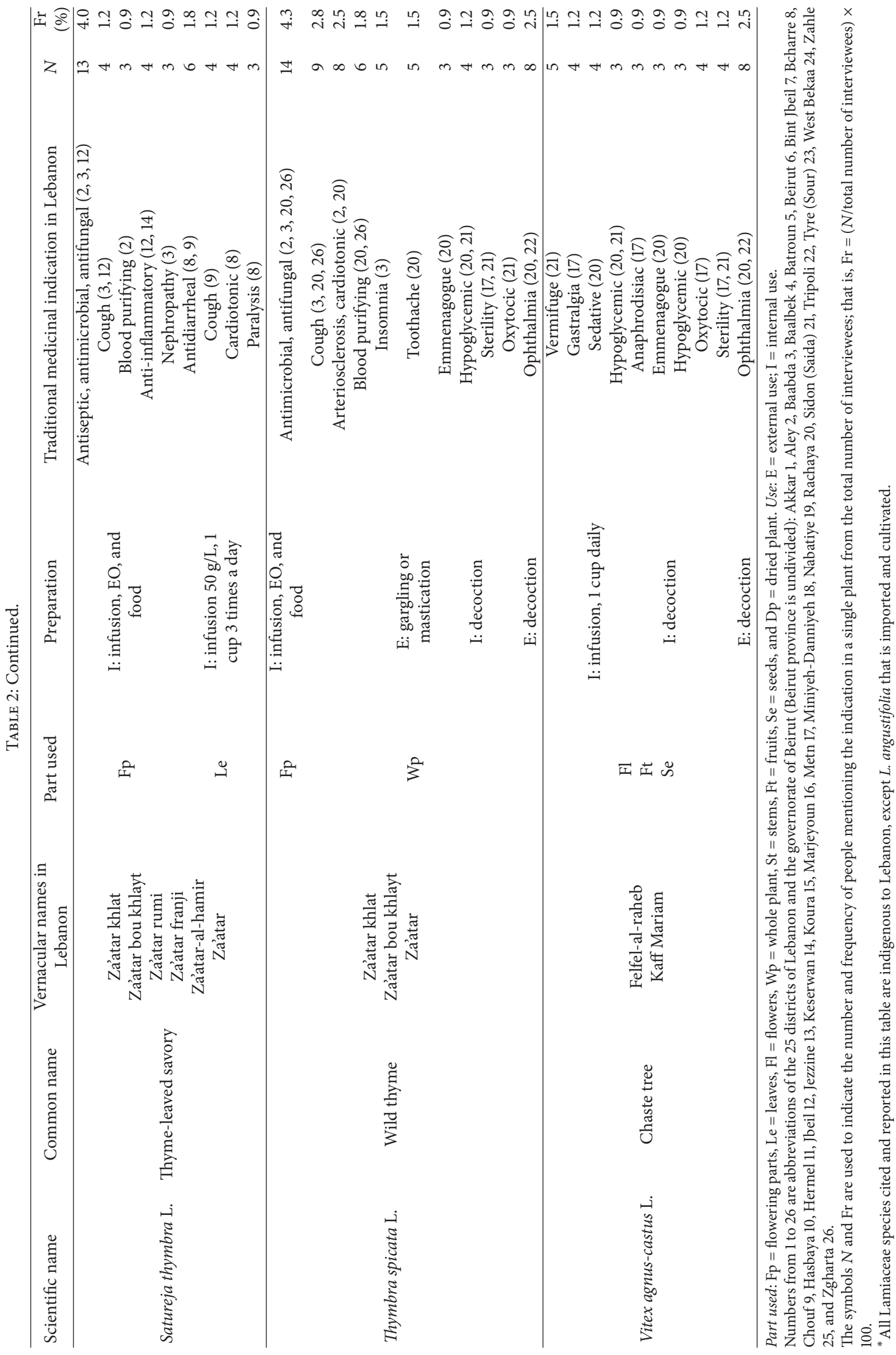


are mainly used to treat gastrointestinal disorders and microbial infections (Table 3). Almost all of them are described to possess antiseptic, antimicrobial, or antifungal properties, and a significant proportion of the EOs has been reported to be applied locally to cure microbial infections (57.1\%).

3.5. Number of Districts Describing the Use of Each Lamiaceae Species. The ethnopharmacological use of Rosmarinus officinalis and Origanum syriacum was mentioned by the largest number of districts (57.7 and 50\%, resp.), while the medicinal use of Coridothymus capitatus, Vitex agnus-castus, and Salvia fruticosa was localized in certain regions of Lebanon (Table 3).

3.6. Comparison with the Ethnopharmacological Uses in Other Mediterranean Countries. Despite the ancestral use of medicinal plants including essential oils in Lebanon, literature reports on Lebanese ethnomedicinal practices are scarce. Nevertheless, previous works have reported the medicinal uses of Lamiaceae species in the Mediterranean basin. Indeed, some of the plant species pointed out in our study are widely distributed and widely acknowledged by local people for medicinal purposes. In many cases, the uses reported in other countries are somewhat comparable to those found in Lebanon. For example, the cultivated lavender Lavandula angustifolia is used in Italy and Turkey as a sedative and antiseptic and to treat cold and rheumatism [27-29]. As for the wild lavender, Lavandula stoechas, it is used in Turkey and Spain for gastrointestinal and cardiovascular diseases [30-34]. Other examples include Coridothymus capitatus and Salvia fruticosa used in Palestine and Israel to treat cold and gastrointestinal disorders [35-37], thymbra spicata used in Turkey for its cardiotonic and hypoglycemic properties, or to treat cough and arthrosclerosis [29, 30,32], Vitex agnus-castus used in Palestine to treat eye inflammation [38], and Mentha spicata and Rosmarinus officinalis that are both used in Italy in the same way as in Lebanon as antiseptics and antimicrobials $[27,39]$.

On the other hand, little is known on the plant species with restricted distribution areas, like Origanum syriacum that is mainly used to treat cold symptoms in Turkey [40] and stomach pain in Jordan [41]. It is also the case of Satureja cuneifolia and Satureja thymbra that are used in Turkey as immunotonic and cardiotonic and to treat cold and flu symptoms $[32,42]$.

3.7. Essential Oils Analyses. Since the VOCs seemed to be relevant in the context of the traditional medicinal use of Lebanese Lamiaceae, it was pertinent to study the chemical composition of their EOs. These are reported in Table 4; the extraction yields and the relative proportions of the components are given.

The yields (v/w, relative to dry weight material) obtained by hydrodistillation ranged from $0.3 \%$ from $V$. agnus-castus flowering tops to $4.1 \%$ from T. spicata leaves. GC and GCMS analyses led to the identification of 75 components accounting for 90.6 to $97.2 \%$ of the total oils (Table 4). It was found that the EOs were essentially composed of
TABLE 3: Most cited preparation and administration mode, plant parts, used and traditional medicinal indications.

\begin{tabular}{|c|c|c|}
\hline Mode of administration & $\mathrm{Nb}$ & $\%$ \\
\hline Internal use & 23 & 71.8 \\
\hline External use & 9 & 28.2 \\
\hline Preparation & $N b$ & $\%$ \\
\hline Infusion & 16 & 40.0 \\
\hline Decoction & 7 & 17.5 \\
\hline EO application & 7 & 17.5 \\
\hline Food & 6 & 15.0 \\
\hline Maceration and local application & 2 & 5.0 \\
\hline Gargle & 1 & 2.5 \\
\hline Mastication & 1 & 2.5 \\
\hline Plant parts used & $N b$ & $\%$ \\
\hline Flowering parts & 9 & 34.6 \\
\hline Leaves & 9 & 34.6 \\
\hline Stems & 3 & 11.5 \\
\hline Flowers & 2 & 7.7 \\
\hline Whole plant & 1 & 3.8 \\
\hline Fruits & 1 & 3.8 \\
\hline Seeds & 1 & 3.8 \\
\hline Traditional medicinal indication & $N b$ & $\%$ \\
\hline $\begin{array}{l}\text { Gastrointestinal disorders (gastritis, } \\
\text { spasmolytic, stomachic...) }\end{array}$ & 13 & 12.4 \\
\hline $\begin{array}{l}\text { Antimicrobial (antiseptic, antifungal, } \\
\text { dermatoses) }\end{array}$ & 12 & 11.4 \\
\hline Hypoglycemic & 10 & 9.5 \\
\hline Rheumatism & 9 & 8.6 \\
\hline Respiratory disorders (bronchitis, cough...) & 8 & 7.6 \\
\hline Antihypertensive & 6 & 5.7 \\
\hline Carminative & 6 & 5.7 \\
\hline Vermifuge & 4 & 3.8 \\
\hline Cardiotonic & 4 & 3.8 \\
\hline Febrifuge & 3 & 2.8 \\
\hline Flu/influenza & 3 & 2.8 \\
\hline Constipation & 3 & 2.8 \\
\hline Hepatitis & 3 & 2.8 \\
\hline Nephropathy & 3 & 2.8 \\
\hline Blood purifying & 3 & 2.8 \\
\hline Various* & 15 & 14.3 \\
\hline $\begin{array}{l}\text { Number of districts describing the use of each } \\
\text { species }\end{array}$ & $\mathrm{Nb}$ & $\%$ \\
\hline Coridothymus capitatus & 4 & 15.4 \\
\hline Lavandula stoechas & 6 & 23.1 \\
\hline Lavandula angustifolia & 6 & 23.1 \\
\hline Mentha spicata & 5 & 19.2 \\
\hline Origanum syriacum & 13 & 50.0 \\
\hline Rosmarinus officinalis & 15 & 57.7 \\
\hline Salvia fruticosa & 9 & 34.6 \\
\hline Satureja cuneifolia & 3 & 11.5 \\
\hline Satureja thymbra & 6 & 23.1 \\
\hline Thymbra spicata & 7 & 26.9 \\
\hline Vitex agnus-castus & 4 & 15.4 \\
\hline
\end{tabular}

$\mathrm{Nb}=$ number of times cited in Table $1 ; \%=$ percentage of each citation.

${ }^{*}$ Indications cited less than three times are listed under various indications. 


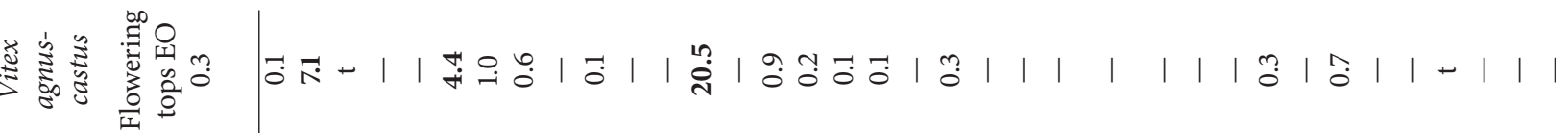

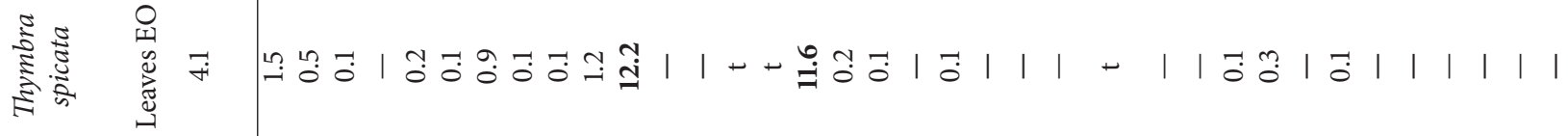
की

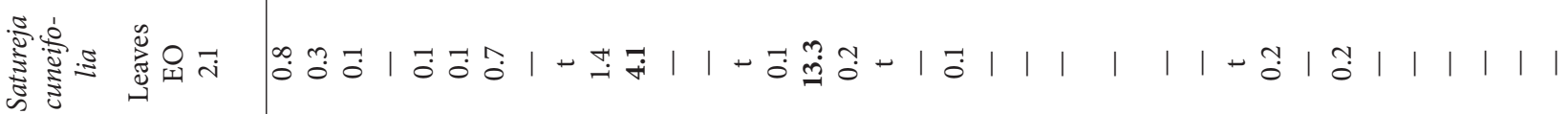

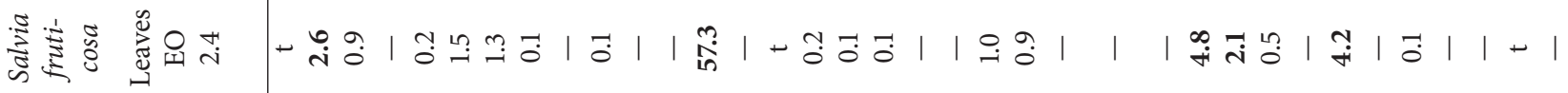

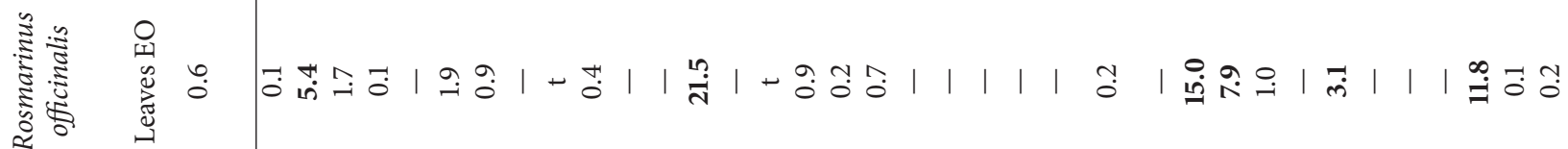

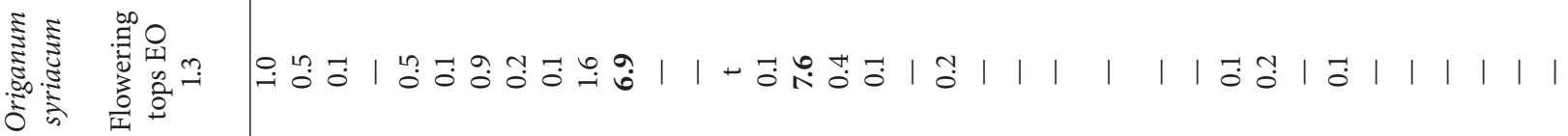
₹

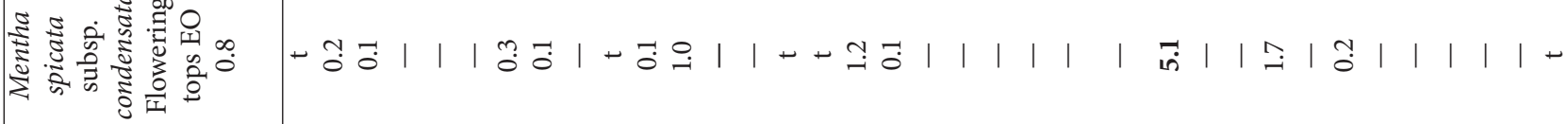

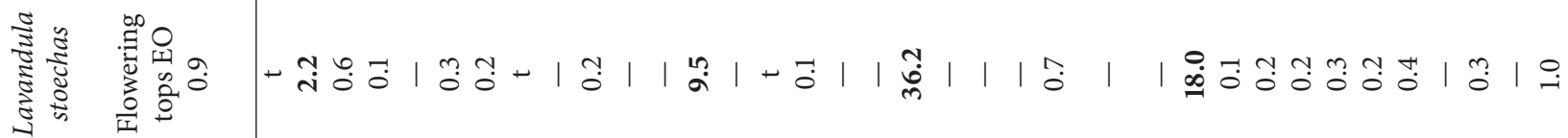

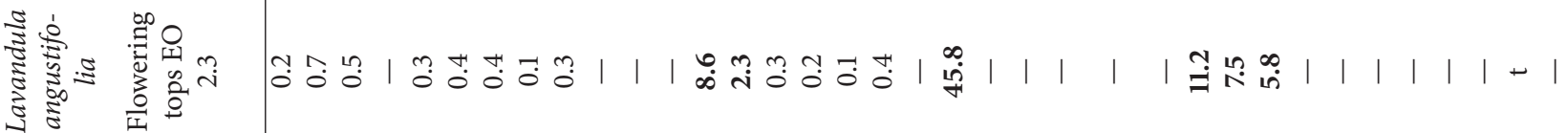

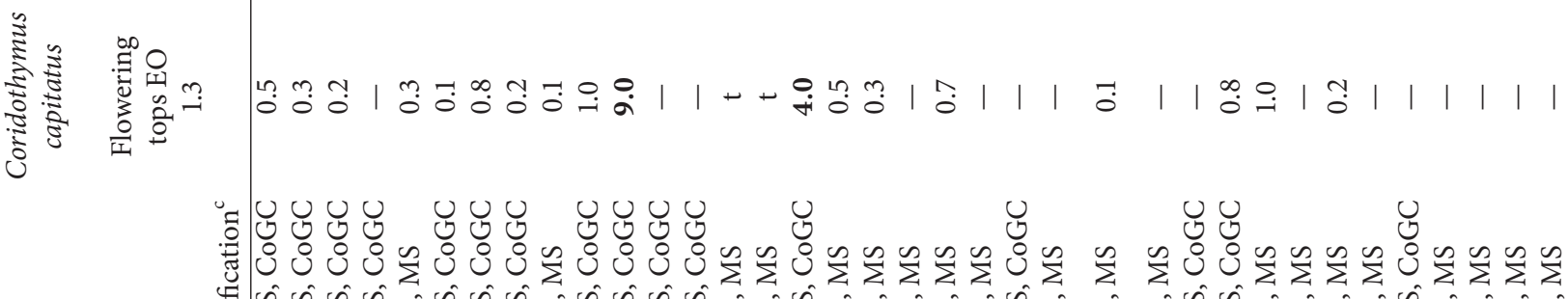

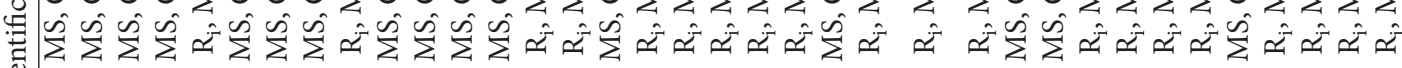

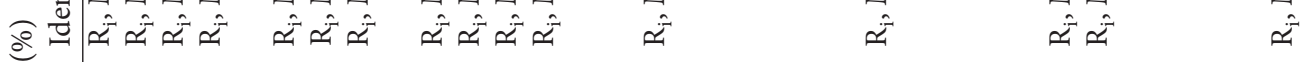

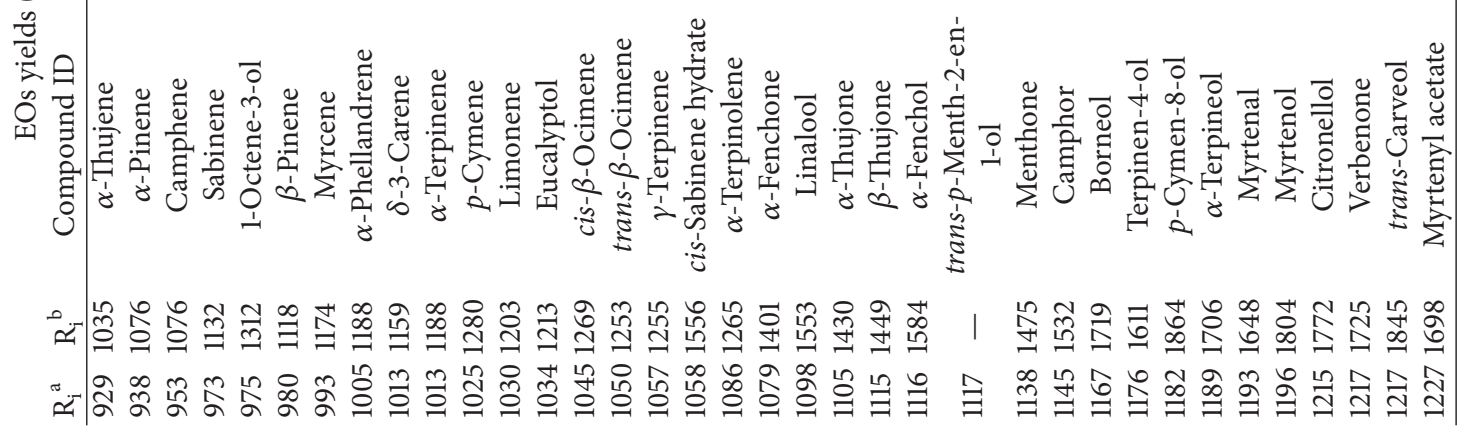




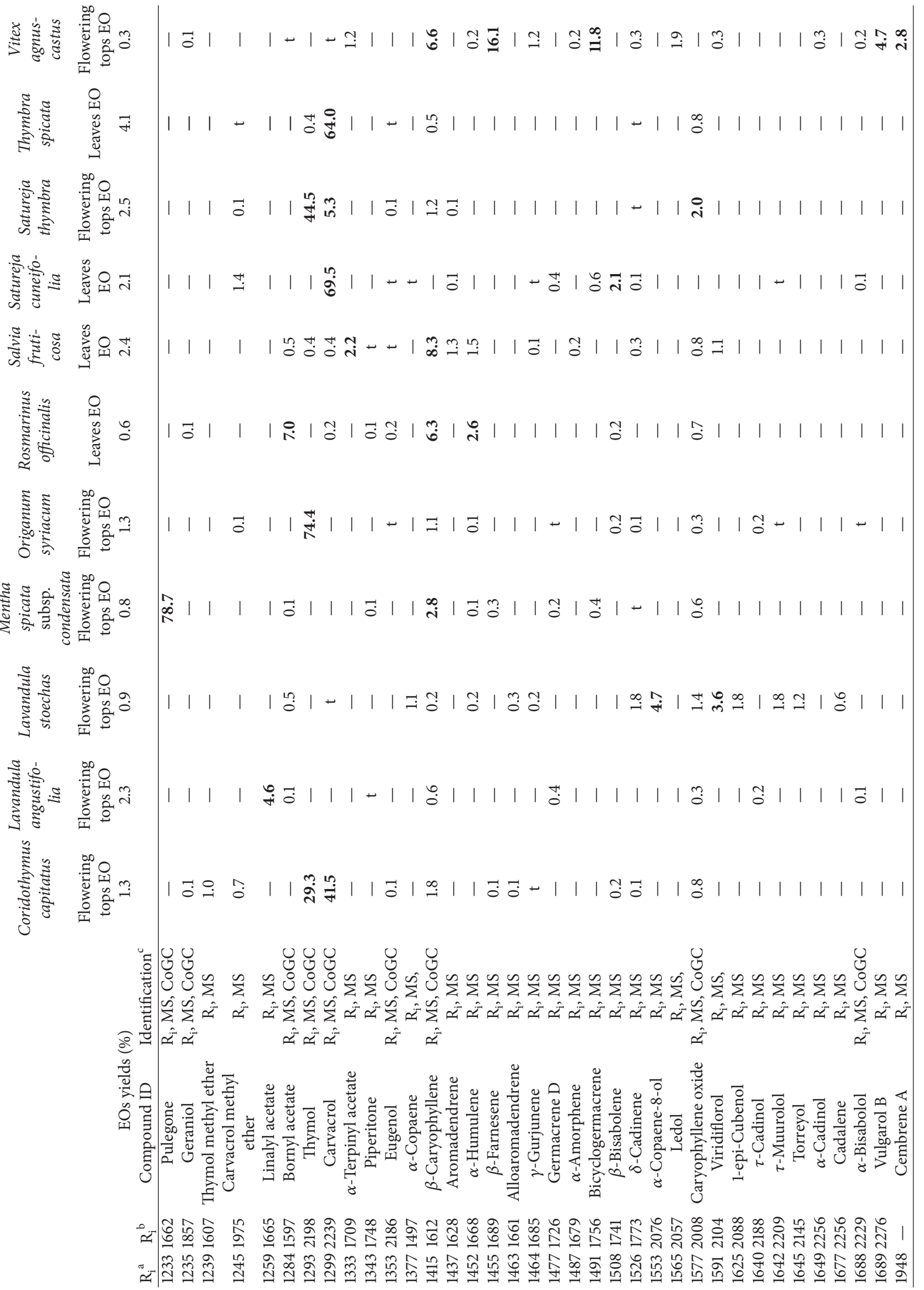




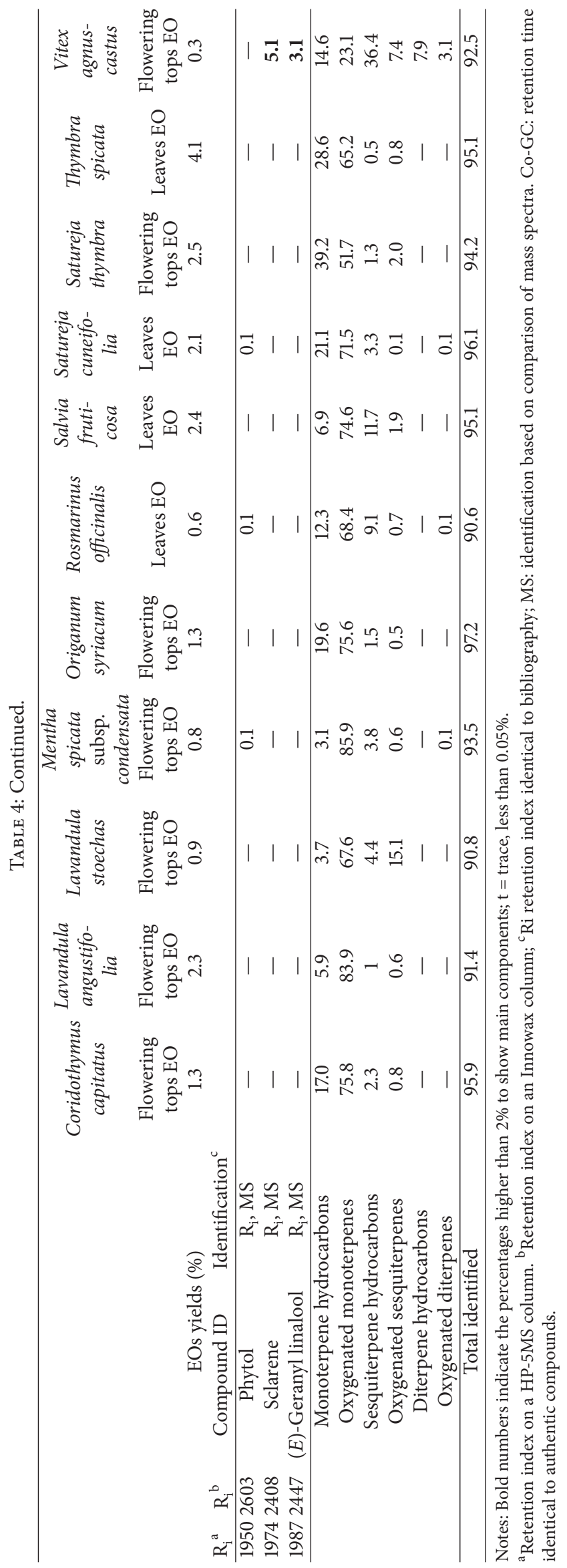


TABLE 5: Antimicrobial activity (MIC in $\mu \mathrm{g} / \mathrm{mL}$ ) of the Lamiaceae oils and there major compounds based on the microdilution method.

\begin{tabular}{|c|c|c|c|c|}
\hline \multirow{3}{*}{ EOs and constituents } & \multicolumn{4}{|c|}{ Microorganisms } \\
\hline & S. aureus & E. coli & C. albicans & T. rubrum \\
\hline & ATCC 29213 & ATCC 25922 & ATCC 10231 & SNB-TR1 \\
\hline Coridothymus capitatus & 64 & 128 & 128 & 64 \\
\hline Lavandula angustifolia & 512 & $>512$ & 512 & 512 \\
\hline Lavandula stoechas & 128 & $>512$ & 512 & 256 \\
\hline Mentha spicata & $>512$ & $>512$ & $>512$ & 512 \\
\hline Origanum syriacum & 128 & 256 & 128 & 64 \\
\hline Rosmarinus officinalis & 512 & $>512$ & 512 & 256 \\
\hline Salvia fruticosa & $>512$ & $>512$ & 512 & 256 \\
\hline Satureja thymbra & 128 & 256 & 128 & 128 \\
\hline Satureja cuneifolia & 128 & 256 & 128 & 128 \\
\hline Thymbra spicata & 128 & 256 & 128 & 64 \\
\hline Vitex agnus castus & 512 & $>512$ & 512 & 512 \\
\hline Thymol & 128 & n.t. & n.t. & 32 \\
\hline Carvacrol & 128 & n.t. & n.t. & 32 \\
\hline Thymol : carvacrol (1:1) & 128 & n.t. & n.t. & 32 \\
\hline Camphor & $>512$ & n.t. & n.t. & 256 \\
\hline Eucalyptol & $>512$ & n.t. & n.t. & 256 \\
\hline Linalool & $>512$ & n.t. & n.t. & 256 \\
\hline$\gamma$-Terpinene & $>512$ & n.t. & n.t. & 512 \\
\hline p-Cymene & $>512$ & n.t. & n.t. & 64 \\
\hline$\alpha$-Fenchone & $>512$ & n.t. & n.t. & 512 \\
\hline Oxacillin & 0.5 & n.t. & n.t. & n.t. \\
\hline Gentamicin & n.t. & 8 & n.t. & n.t. \\
\hline Itraconazole & n.t. & n.t. & 4 & $<0.03$ \\
\hline Fluconazole & n.t. & n.t. & 16 & 2 \\
\hline
\end{tabular}

Notes: n.t. $=$ not tested.

oxygenated monoterpenes (51.7\% to $85.9 \%)$, the only exception being that from Vitex agnus-castus which was mainly composed of sesquiterpene hydrocarbons (36.4\%). Thymol and carvacrol were present in a high relative proportion in several EOs of these Lebanese chemotypes. Thymol was the major constituent of Origanum syriacum (74.4\%), Satureja thymbra (44.5\%), and Coridothymus capitatus (29.3\%) EOs, while carvacrol was highly abundant in the EOs of Satureja cuneifolia (69.5\%), Thymbra spicata (64.0\%), and Coridothymus capitatus (29.3\%). All of these species were also rich in $p$-cymene and $\gamma$-terpinene. The oils of Salvia fruticosa, Rosmarinus officinalis, and Vitex agnus-castus were essentially composed of eucalyptol representing 57.3\%, 21.5\%, and $20.5 \%$ of the total oils, respectively. Pulegone was the main component of the EO of Mentha spicata accounting for $78.7 \%$ of the oil. Wild and cultivated lavender EOs were significantly different; Lavandula stoechas (wild lavender) was mainly composed of $\alpha$-fenchone (26.2\%) while linalool (45.8\%) was the major constituent of Lavandula angustifolia (cultivated lavender).

3.8. Comparison of the Main Components of the Lebanese Lamiaceae Species with Other Countries. The EOs of Vitex agnus-castus, Lavandula stoechas, and Salvia fruticosa have a very similar chemical composition compared to other countries [43-48]. Lavandula angustifolia and Coridothymus capitatus Lebanese EOs are different than those from other regions. According to our study, Lavandula angustifolia EO contains a lower relative proportion of linalyl acetate [49] and Coridothymus capitatus is richer in thymol [50, 51]. The chemical composition of the EO of Rosmarinus officinalis is similar to that reported in Greece [52] but is different from the ones reported in Turkey and Tunisia where the main component of the Lebanese EO, eucalyptol, is absent $[53,54]$. Both thymol and carvacrol chemotypes have been previously reported for our thymol-rich EOs like Satureja thymbra [55, 56] and Origanum syriacum [57] or those in which carvacrol is the main constituent such as Thymbra spicata $[55,58]$ and Satureja cuneifolia $[59,60]$. Likewise, Mentha spicata oil reported in our study belongs to the pulegone chemotype, while a carvone chemotype has also been described in other regions $[61,62]$.

3.9. Antimicrobial Activity. The minimum inhibitory concentrations (MICs) of the Lamiaceae essential oils are presented in Table 5. An oil was considered active if the minimal inhibitory concentration was $128 \mu \mathrm{g} / \mathrm{mL}$ or below [63]. The clinical isolate T. rubrum SNB-TR1 was the most sensitive, followed by the Gram (-) bacterium $S$. aureus and the yeast C. albicans, whereas the Gram (+) bacterium E. coli was more 
resistant. The oil of Coridothymus capitatus was the only EO to possess a significant antibacterial activity against E. coli with a MIC value of $128 \mu \mathrm{g} / \mathrm{mL}$. This EO is rich in both thymol and carvacrol (29.3 and 41.5\%, resp.). Overall, plants EOs with high relative amounts of thymol and/or carvacrol were the most active against $S$. aureus, T. rubrum, and $C$. albicans with MIC values in the range of $64-128 \mu \mathrm{g} / \mathrm{mL}$.

To confirm the origin of the observed antimicrobial activity, the major constituents were tested against the two microorganisms that showed the greatest sensitivity, $S$. aureus and T. rubrum. Indeed, among the tested terpenes, only thymol and carvacrol showed significant antibacterial activity against $S$. aureus (MIC $128 \mu \mathrm{g} / \mathrm{mL}$ ). Against T. rubrum, these two compounds were also very active (MIC $32 \mu \mathrm{g} / \mathrm{mL}$ ), followed by $p$-cymene (MIC $64 \mu \mathrm{g} / \mathrm{mL}$ ). The antimicrobial potential of a combination of thymol and carvacrol in equal proportions was also measured but no synergistic effect was detected. The MIC of the combination of these two compounds was identical to that of each separate compound. The other important constituents, that is, camphor, eucalyptol, linalool, $\gamma$-terpinene, and $\alpha$-fenchone, did not show any significant antimicrobial activity (Table 5).

It has been previously reported that essential oils of Origanum and Thymus species contain mainly phenolic monoterpenes such as carvacrol and thymol and their activities are often attributed to these compounds [64-68].

Our data confirm that these plants or their EOs could indeed be used in local applications for treating mycoses and demonstrate that combinations of thymol and carvacrol are not needed to account for the antifungal property of an EO.

3.10. Correlation Ethnopharmacology: Antimicrobial Activity. Ten species out of the eleven most cited Lamiaceae are used in the Lebanese traditional medicine as antiseptic or antimicrobial agents. Some are even cited specifically as antifungals ( 3 out of 11). Our results corroborate the antimicrobial indications for Coridothymus capitatus, Origanum syriacum, Lavandula stoechas, Satureja thymbra, and Thymbra spicata, indicating that the use of these plant species is most likely linked to the antimicrobial potential of their VOCs. For example, the flowering parts of C. capitatus are used as antiseptic and to treat dermatosis, and our results showed that the EO of the flowering tops can be considered active on all strains tested. The flowering parts of $O$. syriacum, $S$. thymbra, and T. spicata are also used in Lebanon as antiseptic and antimicrobial agents and their EOs proved to be notably active against S. aureus, C. albicans, and T. rubrum (Table 5).

\section{Conclusion}

In conclusion, the ethnobotanical and ethnopharmacological survey of the Lamiaceae plants confirmed that their medical values are widely acknowledged among herbalists and rural communities and that this family of plants is still frequently used in the traditional medicine of Lebanon to treat many ailments, including microbial infections.

This study highlights the in vitro antimicrobial activity of some Lebanese Lamiaceae EOs against human pathogens.
The antimicrobial potential of these EOs originates from their high content in either thymol or carvacrol. These results validate the traditional antimicrobial use of Lamiaceae and lead us to believe that the use of the most active ones of these plants (or their EOs) can be promoted for the treatment of mycoses under topic applications. It should be noted that Lamiaceae herbs have high consumption in the traditional medicine in Lebanon. This might indicate innocuousness [69] although toxicological studies on these species should be encouraged.

\section{Competing Interests}

The authors declare that they have no competing interests.

\section{Acknowledgments}

This work has benefited from an "Investissement d'Avenir" Grant managed by Agence Nationale de la Recherche (CEBA, ref. ANR-10-LABX-25-01).

\section{References}

[1] World Health Organization (WHO), "Antimicrobial resistance," 2014, http://www.who.int/mediacentre/factsheets/fs194/en.

[2] C. T. Kåhrström, "Entering a post-antibiotic era?" Nature Reviews Microbiology, vol. 11, no. 3, p. 146, 2013.

[3] A. J. Alanis, "Resistance to antibiotics: are we in the postantibiotic era?" Archives of Medical Research, vol. 36, no. 6, pp. 697-705, 2005.

[4] A. M. Viens and J. Littmann, "Is antimicrobial resistance a slowly emerging disaster?" Public Health Ethics, vol. 8, no. 3, pp. 255-265, 2015.

[5] F. Bakkali, S. Averbeck, D. Averbeck, and M. Idaomar, "Biological effects of essential oils-a review," Food and Chemical Toxicology, vol. 46, no. 2, pp. 446-475, 2008.

[6] A. E. Edris, "Pharmaceutical and therapeutic potentials of essential oils and their individual volatile constituents: a review," Phytotherapy Research, vol. 21, no. 4, pp. 308-323, 2007.

[7] A. R. Bilia, C. Guccione, B. Isacchi, C. Righeschi, F. Firenzuoli, and M. C. Bergonzi, "Essential oils loaded in nanosystems: a developing strategy for a successful therapeutic approach," Evidence-Based Complementary and Alternative Medicine, vol. 2014, Article ID 651593, 14 pages, 2014.

[8] D. S. Alviano and C. S. Alviano, "Plant extracts: search for new alternatives to treat microbial diseases," Current Pharmaceutical Biotechnology, vol. 10, no. 1, pp. 106-121, 2009.

[9] R. M. Harley, S. Atkins, A. L. Budantsev et al., "Labiatae," in Flowering Plants - Dicotyledons: Lamiales (except Acanthaceae including Avicenniaceae), J. W. Kadereit, Ed., pp. 167-275, Springer, Berlin, Germany, 2004.

[10] D. Rivera Nunez and C. Obon de Castro, "The ethnobotany of the old world labiatae," in Advances in Labiatae Science, R. M. Harley and T. Reynolds, Eds., pp. 455-474, Royal Botanic Gardens, Kew, Richmond, UK, 1992.

[11] M. El Beyrouthy, W. Dhifi, and N. Arnold, "Ethnopharmacological survey of the indigenous Lamiaceae from Lebanon," Acta Horticulturae (ISHS), vol. 997, no. 33, pp. 257-275, 2013.

[12] C. Giuliani and L. Maleci Bini, "Insight into the structure and chemistry of glandular trichomes of Labiatae, with emphasis 
on subfamily Lamioideae," Plant Systematics and Evolution, vol. 276, no. 3-4, pp. 199-208, 2008.

[13] M. El Beyrouthy, N. Arnold, A. Delelis-Dusollier, and F. Dupont, "Plants used as remedies antirheumatic and antineuralgic in the traditional medicine of Lebanon," Journal of Ethnopharmacology, vol. 120, no. 3, pp. 315-334, 2008.

[14] M. E. Beyrouthy, "Contribution à l'ethnopharmacologie libanaise et aux Lamiaceae du Liban," Acta Botanica Gallica, vol. 156, no. 3, pp. 515-521, 2009.

[15] G. Penso, "The role of WHO in the selection and characterization of medicinal plants (vegetable drugs)," Journal of Ethnopharmacology, vol. 2, no. 2, pp. 183-188, 1980.

[16] P. Mouterde, Nouvelle Flore du Liban et de la Syrie, Distribution Librairie Orientale, Beirut, Lebanon, 1983.

[17] B. Bremer, K. Bremer, M. W. Chase et al., "An update of the Angiosperm Phylogeny Group classification for the orders and families of flowering plants: APG II," Botanical Journal of the Linnean Society, vol. 141, no. 4, pp. 399-436, 2003.

[18] European Pharmacopoeia, Council of Europe, Strasbourg, France, 3rd edition, 1997.

[19] W. Jennings and T. Shibamoto, Qualitative Analysis of Flavour and Fragrance Volatiles by Glass Capillary Gas Chromatography, Academic Press, New York, NY, USA, 1980.

[20] N. W. Davies, "Gas chromatographic retention indices of monoterpenes and sesquiterpenes on methyl silicon and Carbowax 20M phases," Journal of Chromatography A, vol. 503, no. 1, pp. 1-24, 1990.

[21] R. P. Adams, Identification of Essential Oil Components by Gas Chromatography/Mass Spectroscopy, Allured, Carol Stream, Ill, USA, 2007.

[22] M. Khoury, M. El Beyrouthy, N. Ouaini, M. Iriti, V. Eparvier, and D. Stien, "Chemical Composition and Antimicrobial Activity of the Essential Oil of Juniperus excelsa M. Bieb. Growing Wild in Lebanon," Chemistry and Biodiversity, vol. 11, no. 5, pp. 825-830, 2014.

[23] Clinical and Laboratory Standards, "Reference method for broth dilution antifungal susceptibility testing of filamentous fungi," Approved Standard M38-A2, 2nd edition, CLSI, Wayne, $\mathrm{Pa}, \mathrm{USA}, 2008$.

[24] Clinical and Laboratory Standards, Reference Method for Broth Dilution Antifungal Susceptibility Testing of Yeasts, Approved Standard M27-A3, CLSI, Wayne, Pa, USA, 3rd edition, 2008.

[25] Clinical and Laboratory Standards, Methods for Dilution Antimicrobial Susceptibility Tests for Bacteria That Grow Aerobically, Approved Standard M7-A8, CLSI, Wayne, Pa, USA, 8th edition, 2009.

[26] A. M. S. Rodrigues, P. N. E. T. Theodoro, V. Eparvier et al., "Search for antifungal compounds from the wood of durable tropical trees," Journal of Natural Products, vol. 73, no. 10, pp. 1706-1707, 2010.

[27] B. Menale, O. De Castro, C. Cascone, and R. Muoio, "Ethnobotanical investigation on medicinal plants in the Vesuvio National Park (Campania, Southern Italy)," Journal of Ethnopharmacology, vol. 192, pp. 320-349, 2016.

[28] C. Leto, T. Tuttolomondo, S. La Bella, and M. Licata, "Ethnobotanical study in the Madonie Regional Park (Central Sicily, Italy) - medicinal use of wild shrub and herbaceous plant species," Journal of Ethnopharmacology, vol. 146, no. 1, pp. 90112, 2013.

[29] I. Ugulu, S. Baslar, N. Yorek, and Y. Dogan, “The investigation and quantitative ethnobotanical evaluation of medicinal plants used around Izmir province, Turkey," Journal of Medicinal Plants Research, vol. 3, no. 5, pp. 345-367, 2009.

[30] R. Polat and F. Satil, "An ethnobotanical survey of medicinal plants in Edremit Gulf (Balikesir-Turkey)," Journal of Ethnopharmacology, vol. 139, no. 2, pp. 626-641, 2012.

[31] M. Sağıroğlu, S. Dalgıç, and S. Toksoy, "Medicinal plants used in Dalaman (Muğla), Turkey," Journal of Medicinal Plants Research, vol. 7, no. 28, pp. 2053-2066, 2013.

[32] S. A. Sargin, S. Selvi, and V. López, "Ethnomedicinal plants of Sarigöl district (Manisa), Turkey," Journal of Ethnopharmacology, vol. 171, pp. 64-84, 2015.

[33] B. Gürdal and Ş. Kültür, "An ethnobotanical study of medicinal plants in Marmaris (Muğla, Turkey)," Journal of Ethnopharmacology, vol. 146, no. 1, pp. 113-126, 2013.

[34] F. M. Vázquez, M. A. Suarez, and A. Pérez, "Medicinal plants used in the Barros Area, Badajoz Province (Spain)," Journal of Ethnopharmacology, vol. 55, no. 2, pp. 81-85, 1997.

[35] N. S. A. Hinnawi, An ethnobotanical study of wild edible plants in the Northern West Bank "Palestine" [Thesis], An-Najah National University, Nablus, Palestine, 2010.

[36] M. S. Ali-Shtayeh, Z. Yaniv, and J. Mahajna, "Ethnobotanical survey in the Palestinian area: a classification of the healing potential of medicinal plants," Journal of Ethnopharmacology, vol. 73, no. 1-2, pp. 221-232, 2000.

[37] E. Lev, "Ethno-diversity within current ethno-pharmacology as part of Israeli traditional medicine-a review," Journal of Ethnobiology and Ethnomedicine, vol. 2, article 4, 2006.

[38] N. Jaradat and J. Al-Aqsa, "Medical plants utilized in Palestinian folk medicine for treatment of diabetes mellitus and cardiac diseases," Journal of Al-Aqsa University, no. 9, pp. 1-22, 2005.

[39] P. Fortini, P. Di Marzio, P. Guarrera, and M. Iorizzi, "Ethnobotanical study on the medicinal plants in the Mainarde Mountains (central-southern Apennine, Italy)," Journal of Ethnopharmacology, vol. 184, pp. 208-218, 2016.

[40] S. Demirci and N. Özhatay, "An ethnobotanical study in Kahramanmaraş (Turkey); wild plants used for medicinal purpose in Andırın, Kahramanmaraş," Turkish Journal of Pharmaceutical Sciences, vol. 9, no. 1, pp. 75-92, 2012.

[41] S. A. S. Oran and D. M. H. Al-Eisawi, "Ethnobotanical survey of the medicinal plants in the central mountains (North-South) in Jordan," Journal of Biodiversity and Environmental Sciences, vol. 6, no. 3, pp. 381-400, 2015.

[42] S. A. Sargin, E. Akçicek, and S. Selvi, "An ethnobotanical study of medicinal plants used by the local people of Alaşehir (Manisa) in Turkey," Journal of Ethnopharmacology, vol. 150, no. 3, pp. 860-874, 2013.

[43] D. Stojković, M. Soković, J. Glamočlija et al., "Chemical composition and antimicrobial activity of Vitex agnus-castus L. fruits and leaves essential oils," Food Chemistry, vol. 128, no. 4, pp. 1017-1022, 2011.

[44] A. Habbab, K. Sekkoum, N. Belboukhari, A. Cheriti, and H. Y. Aboul-Enein, "Essential oil chemical composition of Vitex agnus-castus L. from Southern-West Algeria and its antimicrobial activity," Current Bioactive Compounds, vol. 12, no. 1, pp. 5160, 2016.

[45] C. N. Hassiotis, "Chemical compounds and essential oil release through decomposition process from Lavandula stoechas in Mediterranean region," Biochemical Systematics and Ecology, vol. 38, no. 4, pp. 493-501, 2010.

[46] H. Kirmizibekmez, B. Demirci, E. Yeşilada, K. H. C. Başer, and F. Demirci, "Chemical composition and antimicrobial activity of 
the essential oils of Lavandula stoechas L. ssp. stoechas growing wild in Turkey," Natural Product Communications, vol. 4, no. 7, pp. 1001-1006, 2009.

[47] I. Cvetkovikj, G. Stefkov, M. Karapandzova, and S. Kulevanova, "Essential oil composition of Salvia fruticosa Mill. populations from Balkan Peninsula," Macedonian Pharmaceutical Bulletin, vol. 61, no. 1, pp. 19-26, 2015.

[48] J. Z. Al-Kalaldeh, R. Abu-Dahab, and F. U. Afifi, "Volatile oil composition and antiproliferative activity of Laurus nobilis, Origanum syriacum, Origanum vulgare, and Salvia triloba against human breast adenocarcinoma cells," Nutrition Research, vol. 30, no. 4, pp. 271-278, 2010.

[49] R. Prusinowska and K. B. Śmigielski, "Composition, biological properties and therapeutic effects of lavender (Lavandula angustifolia L). A review," Herba Polonica, vol. 60, no. 2, pp. 5666, 2014.

[50] F. Tateo, M. Mariotti, and M. Bononi, "Essential oil composition and enantiomeric distribution of some monoterpenoid components of Coridothymus capitatus (L.) Rchb. Grown on the Island of Kos (Greece)," Journal of Essential Oil Research, vol. 10, no. 3, pp. 241-244, 1998.

[51] G. Economou, G. Panagopoulos, P. Tarantilis et al., "Variability in essential oil content and composition of Origanum hirtum L., Origanum onites L., Coridothymus capitatus (L.) and Satureja thymbra L. populations from the Greek island Ikaria," Industrial Crops and Products, vol. 33, no. 1, pp. 236-241, 2011.

[52] G. Beretta, R. Artali, R. M. Facino, and F. Gelmini, "An analytical and theoretical approach for the profiling of the antioxidant activity of essential oils: the case of Rosmarinus officinalis L.", Journal of Pharmaceutical and Biomedical Analysis, vol. 55, no. 5, pp. 1255-1264, 2011.

[53] S. Irmak, K. Solakyildirim, A. Hesenov, and O. Erbatur, "Study on the stability of supercritical fluid extracted rosemary (Rosmarinus offcinalis L.) essential oil," Journal of Analytical Chemistry, vol. 65, no. 9, pp. 899-906, 2010.

[54] Y. Zaouali, T. Bouzaine, and M. Boussaid, "Essential oils composition in two Rosmarinus officinalis $\mathrm{L}$. varieties and incidence for antimicrobial and antioxidant activities," Food and Chemical Toxicology, vol. 48, no. 11, pp. 3144-3152, 2010.

[55] T. Marković, P. Chatzopoulou, J. Siljegović et al., "Chemical analysis and antimicrobial activities of the essential oils of Satureja thymbra L. and Thymbra spicata L. and their main components," Archives of Biological Sciences, vol. 63, no. 2, pp. 457-464, 2011.

[56] A. C. Gören, G. Topçu, G. Bilsel, M. Bilsel, J. M. Wilkinson, and H. M. A. Cavanagh, "Analysis of essential oil of Satureja thymbra by hydrodistillation, thermal desorber, and headspace GC/MS techniques and its antimicrobial activity," Natural Product Research, vol. 18, no. 2, pp. 189-195, 2004.

[57] B. Lukas, C. Schmiderer, C. Franz, and J. Novak, "Composition of essential oil compounds from different Syrian populations of Origanum syriacum L. (Lamiaceae)," Journal of Agricultural and Food Chemistry, vol. 57, no. 4, pp. 1362-1365, 2009.

[58] G. Tümen, N. Ermin, T. Özek, M. Kürkçüoğlu, and K. H. C. Baser, "Composition of essential oils from two varieties of Thymbra spicata L.," Journal of Essential Oil Research, vol. 6, no. 5, pp. 463-468, 1994.

[59] B. Biavati, M. Özcan, and R. Piccaglia, "Composition and antimicrobial properties of essential oils Satureja cuneifolia Ten. and Tymbra sintenisii Bornm. et Aznav subsp. isaurica P.H. Davis," Annals of Microbiology, vol. 54, no. 4, pp. 393-401, 2004.
[60] C. Tümen, N. Kirimer, N. Ermin, and K. H. C. Başer, "The essential oil of Satureja cuneifolia," Planta Medica, vol. 64, no. 1, pp. 81-83, 1998.

[61] I. Telci, I. Demirtas, E. Bayram, O. Arabaci, and O. Kacar, "Environmental variation on aroma components of pulegone/piperitone rich spearmint (Mentha spicata L.)," Industrial Crops and Products, vol. 32, no. 3, pp. 588-592, 2010.

[62] Y. Shahbazi, "Chemical composition and in vitro antibacterial activity of Mentha spicata essential oil against common foodborne pathogenic bacteria," Journal of Pathogens, vol. 2015, Article ID 916305, 5 pages, 2015.

[63] P. Cos, A. J. Vlietinck, D. Vanden Berghe, and L. Maes, "Anti-infective potential of natural products: how to develop a stronger in vitro 'proof-of-concept," Journal of Ethnopharmacology, vol. 106, no. 3, pp. 290-302, 2006.

[64] R. J. W. Lambert, P. N. Skandamis, P. J. Coote, and G.-J. E. Nychas, "A study of the minimum inhibitory concentration and mode of action of oregano essential oil, thymol and carvacrol," Journal of Applied Microbiology, vol. 91, no. 3, pp. 453-462, 2001.

[65] M. C. Rota, A. Herrera, R. M. Martínez, J. A. Sotomayor, and M. J. Jordán, "Antimicrobial activity and chemical composition of Thymus vulgaris, Thymus zygis and Thymus hyemalis essential oils," Food Control, vol. 19, no. 7, pp. 681-687, 2008.

[66] A. Giweli, A. M. Džamic, M. Sokovic, M. S. Ristic, and P. D. Marin, "Antimicrobial and antioxidant activities of essential oils of Satureja thymbra growing wild in libya," Molecules, vol. 17, no. 5, pp. 4836-4850, 2012.

[67] A. Barakat, L. Hanna Wakim, N. A. Apostolides, G. Srour, and M. El Beyrouthy, "Variation in the essential oils of Thymbra spicata L. growing wild in Lebanon according to the date of harvest," Journal of Essential Oil Research, vol. 25, no. 6, pp. 506511, 2013.

[68] M. Zabka and R. Pavela, "Antifungal efficacy of some natural phenolic compounds against significant pathogenic and toxinogenic filamentous fungi," Chemosphere, vol. 93, no. 6, pp. 10511056, 2013.

[69] The European Parliament and the Council of the European Union, "Directive 2004/24/EC," Official Journal of the European Union, vol. 136, pp. 85-90, 2004. 


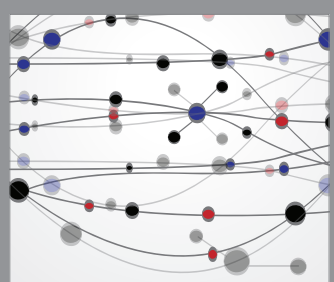

The Scientific World Journal
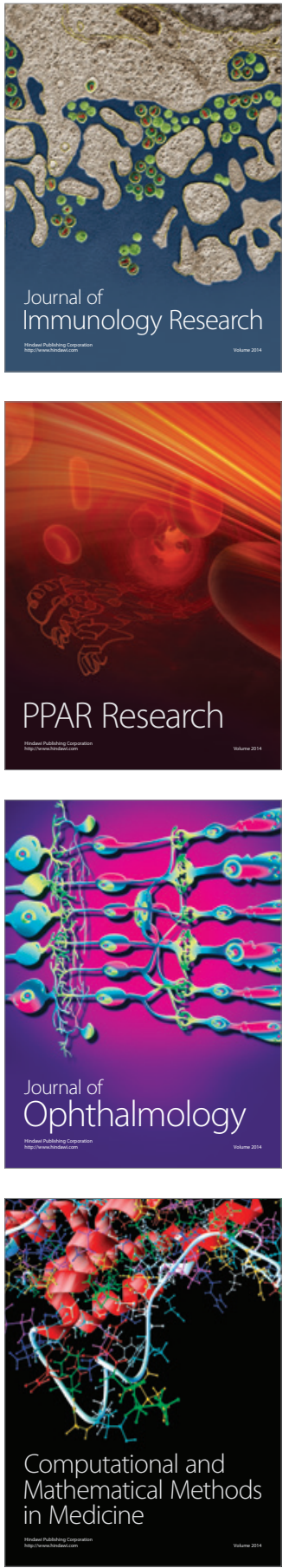

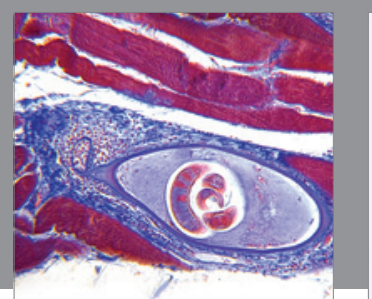

Gastroenterology Research and Practice

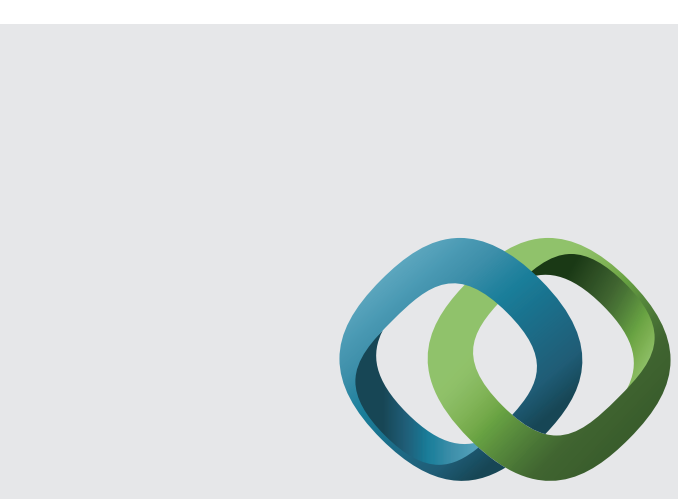

\section{Hindawi}

Submit your manuscripts at

http://www.hindawi.com
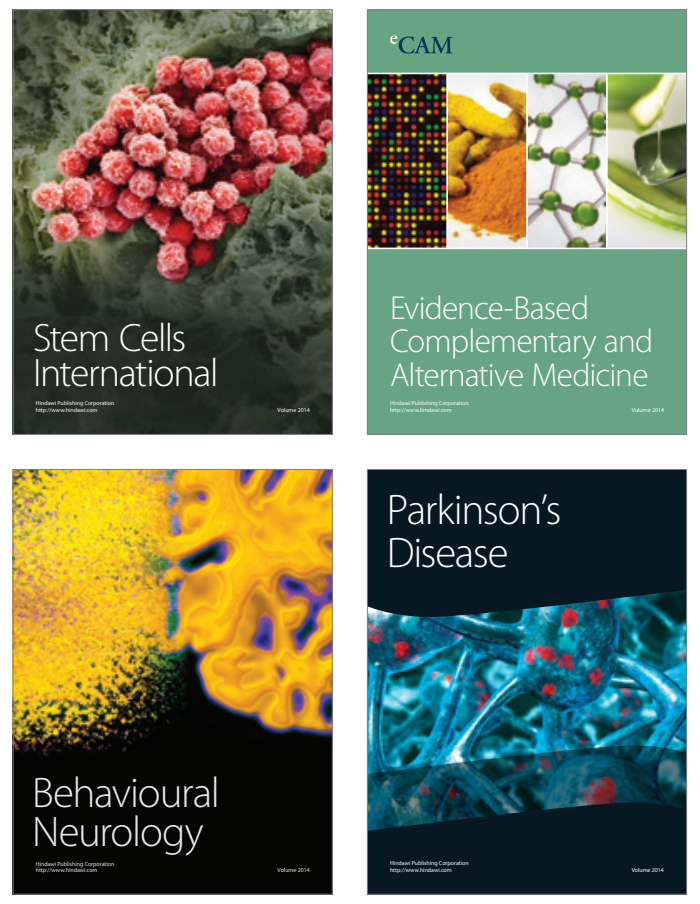
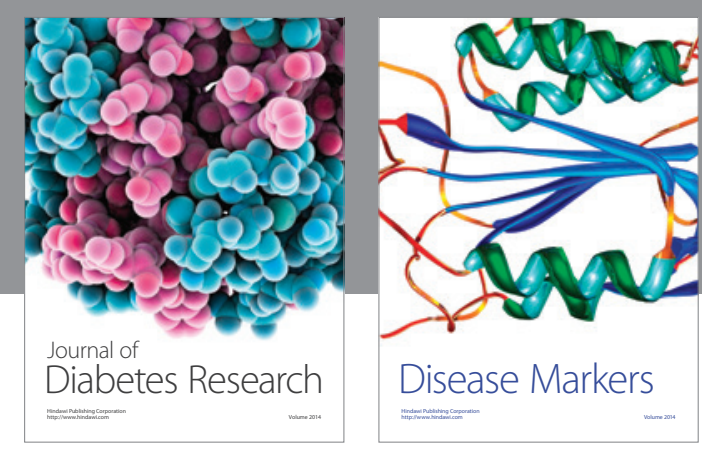

Disease Markers
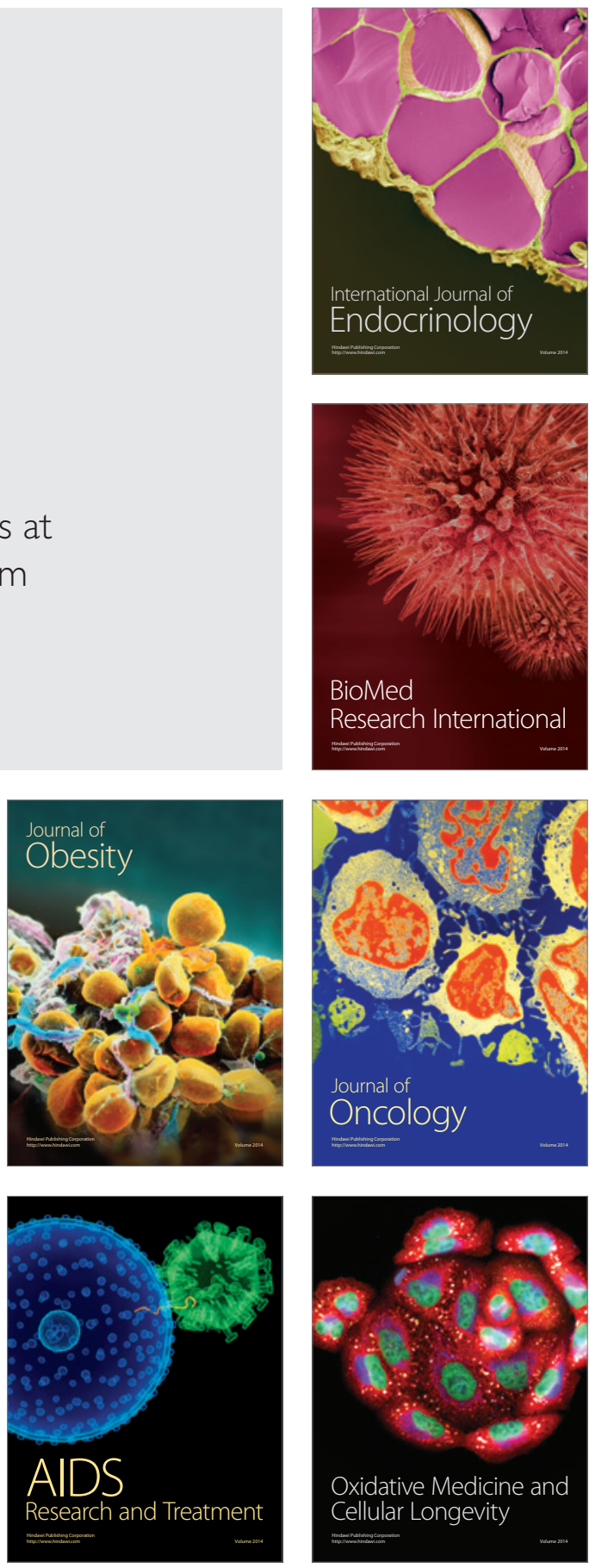